\title{
KIEDY OTOCZENIE MA ZNACZENIE: ŚWIADOMOŚĆ ZDROWOTNA I WZORCE W OTOCZENIU SPOŁECZNYM JAKO DETERMINANTY POZIOMU AKTYWNOŚCI FIZYCZNEJ STUDENTÓW
}

\begin{abstract}
Streszczenie: Artykuł przedstawia problematykę aktywności fizycznej w opinii studentów uczelni warszawskich. W pracy przedstawiono autorski model świadomości zdrowotnej, na podstawie którego wyodrębniono trzy profile, które przypisano młodzieży akademickiej o wysokim, przeciętnym i niskim poziomie świadomości zdrowotnej, co stało się głównym kryterium różnicującym postrzeganie domu rodzinnego i najbliższego otoczenia jako źródła troski o zdrowie. Z badań wynika, że osoby o wysokim poziomie świadomości zdrowotnej częściej w swoim otoczeniu mogą znaleźć osoby uprawiające sport i troszczące się o zdrowie, co może wskazywać na transmisję wzorców zachowań zdrowotnych w środowisku rodzinnym i wzajemnego mobilizowania się do podejmowania działań na rzecz zdrowia.
\end{abstract}

Słowa kluczowe: zdrowie, świadomość zdrowotna, aktywność fizyczna studentów, otoczenie sprzyjające zdrowiu, zachowania prozdrowotne.

\section{Aktywność fizyczna - portret studentów polskich}

Zdaniem Barbary Woynarowskiej, „aktywność fizyczna, w połączeniu ze zdrowym żywieniem, jest jedną z podstawowych potrzeb człowieka oraz kluczowym warunkiem zachowania i wzmacniania zdrowia" (Woynarowska 2010, s. 317). Autorka definiuje ją jako „wszystkie czynności i zajęcia związane z wysiłkiem fizycznym i ruchem (pracą mięśni), w czasie których czynność serca i oddech przyspiesza się, pojawia się uczucie ciepła (i często pocenie się)” (Woynarowska 2010, s. 318).

Ze względu na ogromne znaczenie aktywności fizycznej nie tylko w stymulacji i wspomaganiu rozwoju, ale także w zapobieganiu mechanizmom patogenetycznym, problematyka ta jest ostatnimi czasy jednym z podstawowych przedmiotów refleksji naukowej (Biernat 2011; Binkowska-Bury 2009; Dornowski 2004; 
Florkiewicz 2004; Gacek 2003; Gaweł 2003; Gniazdowski 1990; Grabara, Szopa 2011; Kijo 2004; Krajewska, Słowik-Gabryelska 2008; Makuła 1999; Molewski i in. 2012; Nowak-Zaleska, Zaleski 2004; Pawlik 2003; Popławska, Huk-Wieliczuk 1997; Sochocka, Wojtyłko 2013; Suliga 2004; Szczodrowska, Krysiak 2013; Zarzycki 2004).

Ciekawych rezultatów dostarczają analizy Marka Molewskiego i in. (2012), którzy przedstawili problematykę aktywności fizycznej polskich studentów w porównaniu $\mathrm{z}$ ich europejskimi rówieśnikami. $\mathrm{Z}$ badań wynika, że prawie 60 proc. polskiej młodzieży akademickiej wskazuje, że sport ma ogromne znaczenie w ich życiu. Większą wagę przywiązują do niego studenci angielscy (65 proc.), mniejszą natomiast duńscy (53,57 proc.), ukraińscy (46,15 proc.) i amerykańscy (41,18 proc.). Z kolei badania Waldemara Makuły (1999), Anny Gaweł (2003), Alicji Nowak-Zaleskiej i Ryszarda Zaleskiego (2004) oraz Marii Gacek (2003) pokazały, że mimo iż studenci doceniają powagę aktywności fizycznej i znają jej pozytywny wpływ na zdrowie, to nie angażują się w nią w wystarczającym stopniu.

Z badań Molewskiego (2012) wynika, że 39,39 proc. polskich studentów poświęca na aktywność fizyczną więcej niż dwie godziny w tygodniu, przy czym podobne zachowania deklaruje 62,96 proc. studentów duńskich i 45 proc. brytyjskich. Około 47 proc. Amerykanów deklaruje uprawianie sportu poniżej dwóch godzin tygodniowo, w wypadku 61,64 proc. Ukraińców jest to poniżej jednej godziny w tygodniu. W sferze deklaratywnej, z badań Lucyny Sochockej i Aleksandra Wojtyłko (2013), wynika, że 79,5 proc. studentów określiła siebie mianem osoby aktywnej. Należy jednak wspomnieć, że poziom aktywności ruchowej wśród studentów zwiększa się proporcjonalnie wraz ze wzrostem poziomu wykształcenia rodziców osób badanych i pochodzenia ze środowiska miejskiego (Gniazdowski 1990; Suliga 2004). Badania pokazują, że proaktywny tryb życia wpływał pozytywnie na inne elementy zdrowego stylu życia, jak właściwe odżywianie, odpowiednią liczbę godzin snu czy ograniczone stosowanie używek (Suliga 2004). Osoby, które więcej ćwiczą, spożywają większe ilości warzyw i owoców, częściej konsumują ryby oraz przetwory mleczne. Należy jednak zaznaczyć, że główną motywacją studentów do podejmowania aktywności fizycznej był ładny wygląd oraz aspekty zdrowotne (Gaweł 2003; Nowak-Zaleska, Zaleski 2004; Pawlik 2003). Instrumentalny charakter motywacji potwierdza również Monika Binkowska-Bury (2009), która w swoich badaniach pokazała, że 66,8 proc. studentów podejmowało aktywność fizyczną z troski o własną sylwetkę, 56,8 proc. chciało uzyskać lepszą kondycję fizyczną, a 42,6 proc. - rozładować stres. Z kolei analizując przyczyny niskiej aktywności fizycznej, studenci najczęściej wskazywali na brak czasu (USA - 68,75 proc.; Ukraina - 61,54 proc.; Dania - 55 proc.; Anglia - 52,63 proc. i Polska - 49,48 proc.) (Molewski 2012, s. 59) oraz brak motywacji i środków finansowych. Z badań Binkowskiej-Bury wynika, że „wśród ćwiczeń ruchowych preferowanych przez osoby podejmujące aktywność fizyczną codziennie największe znaczenie miały spacery $(62,6$ proc. wskazań) oraz podejmowanie ćwiczeń w domu (13,6 proc. wskazań)" (Binkowska-Bury 2009, s. 58). Innych rezultatów dostarczyli Sochocka 
i Wojtyłko, którzy twierdzili, że „Formami aktywności fizycznej podejmowanymi najczęściej przez badanych studentów są: jazda na rowerze $-40,5$ proc. $(n=4220)$, gry zespołowe $-27,1$ proc. $(n=4147)$, spacer z psem $-27,1$ proc. $(n=4147)$, zajęcia grupowe (aerobic, zumba, salsa) $-21,2$ proc. $(\mathrm{n}=4115)$ oraz pływanie $-20,8$ proc. $(\mathrm{n}=4113)$ " (Sochocka, Wojtyłko 2013, s. 55).

Podsumowując, można stwierdzić, że młodzież akademicka jest świadoma roli, jaką aktywność fizyczna odgrywa w życiu codziennym. Niestety, pomimo tej wiedzy nadal niewystarczająca liczba młodych uprawia sport, co może mieć negatywny wpływ na ich kondycję zdrowotną, a tym samym na funkcjonowanie całego społeczeństwa. Owa dysproporcja między zdawaniem sobie sprawy z korzyści uprawiania sportu a faktycznym działaniem na rzecz zdrowia przyczyniła się do refleksji nad świadomością zdrowotną młodzieży akademickiej.

\section{Świadomość zdrowotna - konceptualizacja pojęcia}

W literaturze przedmiotu rzadko występują definicje „świadomości zdrowotnej”, które wyczerpywałyby omawiane pojęcie w sposób naukowy i holistyczny. Taka sytuacja skutkuje nie tylko swoistym chaosem terminologicznym, ale także niejasnością interpretacyjną wyników badań. Naukowe ujęcia tego tematu wpisują się głównie w nurt koncepcji zachowań zdrowotnych. Można więc wysnuć wniosek, że interpretowanie, czym jest świadomość zdrowotna, w kontekście samej wiedzy, nie jest jedynie słusznym i pożądanym zjawiskiem, gdyż zawężałoby jej rolę i znaczenie. Takie ujęcie poruszanej tematyki jest więc ograniczające. Jak twierdzi Zofia Ratajczak, „świadomość zdrowotna jest złożoną strukturą poznawczą, której regulacyjna rola w zdrowotnym zachowaniu się człowieka polega na ukierunkowaniu i organizowaniu zachowań" (Ratajczak 1997, s. 58). Zdaniem autorki na świadomość zdrowotną składają się: wzorce percepcyjne; wiedza o zdrowiu i chorobach oraz miejsce zdrowia w hierarchii wartości.

Ciekawy pod względem praktycznego wykorzystania wydaje się an Interaction Model to Facilitate Health Awareness and Behavior Change („Interakcyjny Model Świadomości Zdrowotnej i Zmiany Zachowania"), autorstwa Marshalla W. Kreutera (1976). Autor zaprezentował strategię zmiany zachowań zdrowotnych poprzez rozwój odpowiedzialności jednostki za: 1) proces definiowania i rozumienia zdrowia; 2) ocenę własnego stanu zdrowia; 3) podejmowanie decyzji w zakresie zmian tych jego elementów, które według jednostki są niezadowalające (Kreuter 1976). Takie ujęcie tematu pozwala na podjęcie próby wyjaśnienia zachowań ludzkich oraz ich kształtowania, za pomocą konkretnych oddziaływań na świadomość jednostki $\mathrm{w}$ procesie edukacji.

W związku z niejednorodnością terminologiczną, rozważając definicję świadomości zdrowotnej na gruncie nauk pedagogicznych, przyjmuje się, że stanowi ona swoistą formę świadomości, odwołującą się do samoświadomości, która odbiera informacje poprzez zespół procesów wewnętrznych oraz steruje zachowaniami 
zdrowotnymi człowieka, łącząc się tym samym ze świadomością społeczną, odzwierciedlającą się w sposobie myślenia ludzi oraz funkcjonujących społecznie normach rozumienia i wartościowania zdrowia, jak również informacjach i przekonaniach na temat zdrowia. Dotyczy postrzegania związków między wiedzą na temat postępowania w celu utrzymania prawidłowego zdrowia a rzeczywistymi postawami i zachowaniami zdrowotnymi. Takie ujęcie świadomości zdrowotnej wskazuje na interakcje pomiędzy doświadczeniami jednostki, jej przemyśleniami oraz swoistymi umiejętnościami przekształcania nabytej wiedzy zdrowotnej w codzienne zachowania prozdrowotne, które można już rozpatrywać na gruncie społecznym.

W konsekwencji, na potrzeby badań wyodrębniono następujące komponenty świadomości zdrowotnej:

1) rozumienie przez jednostkę pojęcia zdrowia;

2) postawy zdrowotne, obejmujące wiedzę, zachowania zdrowotne oraz miejsce zdrowia w hierarchii wartości;

3) poczucie sprawstwa nad własnym zdrowiem, interpretowanym w kontekście umiejscowienia kontroli zdrowia w wymiarze wewnętrznym, wpływu innych ludzi na zdrowie oraz wpływu przypadku na zdrowie.

Wszystkie przedstawione powyżej elementy są uwarunkowane procesem edukacyjnym (formalnym, nieformalnym i pozaformalnym), odbywającym się w środowisku rodzinnym, rówieśniczym i lokalnym, w tym również szkolnym czy akademickim. Powyższa propozycja jest głosem w debacie dotyczącej edukacji zdrowotnej czy ogólniej - zdrowia i jego świadomości, stanowiąc jeden z punktów wyjścia w konstruowaniu teorii w ramach omawianego zagadnienia.

\section{Metodologia badań własnych}

Celem podjętych badań jest ukazanie różnic w podejmowaniu aktywności fizycznej, w zależności od prezentowanego poziomu świadomości zdrowotnej. W badaniach wyodrębniono trzy poziomy świadomości: niski, przeciętny, wysoki, które stały się główną zmienną różnicującą podejmowaną aktywność fizyczną.

Skorzystano również z metody sondażu diagnostycznego, testów psychologicznych oraz metody badań testowych, co przełożyło się na następujące narzędzia badawcze: kwestionariusz własny „Test Wiedzy o Zdrowiu”, kwestionariusz własny „Ankieta”; „Inwentarz Zachowań Zdrowotnych” Zygfryda Juczyńskiego, „Lista Kryteriów Zdrowia” Juczyńskiego oraz „Wielowymiarowa Skala Umiejscowienia Kontroli Zdrowia" w adaptacji Juczyńskiego.

W badaniu wzięło udział 589 osób. Zdecydowana większość ankietowanych to kobiety $(66,3$ proc.; $n=390)$, natomiast mężczyźni stanowili jedną trzecią respondentów (33,6 proc.; $\mathrm{n}=198$ ) (brak danych $\mathrm{n}=1 ; 0,2$ proc.). Wiek badanych mieścił się w przedziale od 20 do 56 lat. Rozpiętość ta uwarunkowana była przeprowadzaniem 
badań także wśród słuchaczy studiów niestacjonarnych, znakomita jednak większość badanych (94,2 proc.) należała do przedziału wiekowego od 20 do 25 lat.

Ankietowani pochodzili z warszawskich uczelni wyższych, wśród których znalazły się takie uczelnie, jak: Akademia Pedagogiki Specjalnej, Politechnika Warszawska, Uniwersytet Warszawski, Pedagogium, Wojskowa Akademia Techniczna oraz Uniwersytet Kardynała Stefana Wyszyńskiego. Dobór próby był celowy.

Wyniki uzyskane w poszczególnych narzędziach przetworzono w procesie wyłaniającym profile respondentów o wysokim, przeciętnym i niskim poziomie świadomości zdrowotnej.

Na podstawie uzyskanych rezultatów w poszczególnych narzędziach stworzono „Indeks Świadomości Zdrowotnej”, który powstał w oparciu o „Inwentarz Zachowań Zdrowotnych” (IZZ), „Wielowymiarową Skalę Umiejscowienia Kontroli Zdrowia” (MHLC), miejsce zdrowia w hierarchii wartości oraz „Test Wiedza o Zdrowiu" (TWoZ). Wartości uzyskane w poszczególnych narzędziach badawczych (głównie IZZ i MHLC) zostały przekształcone na jednostki standaryzowane i zinterpretowane stosownie do właściwości charakteryzujących skalę stenową. $\mathrm{Na}$ tej podstawie wyniki w granicach 1-4 stena traktuje się jako wyniki niskie, 5-6 jako wyniki przeciętne, zaś 7-10 stena jako wyniki wysokie. Odrębne podziały utworzono dla zdrowia w hierarchii wartości. Wysoką wartość zdrowia przyjęto dla pierwszego lub drugiego miejsca zdrowia w ogólnej hierarchii wartości jednostki, wartość przeciętną - dla wartości zdrowia znajdującej się na 3, 4 lub 5 miejscu w ogólnej hierarchii wartości badanych oraz wartość niską - na miejscu niższym niż 5. Natomiast $\mathrm{w}$ „Teście Wiedzy o Zdrowiu” wyodrębniono trzy grupy o niskich wynikach (osoby uzyskujące wyniki od dziewięciu do 11 punktów), o przeciętnych wynikach (osoby uzyskujące wyniki 12-13 punktów) oraz o wynikach wysokich (osoby uzyskujące wyniki powyżej 14 punktów), którym odpowiednio przyporządkowano normy stenowe od 1-4, od 5-6 oraz od 7-10. Poszczególnym przedziałom norm stenowych: IZZ, MHLC oraz TWoZ przyporządkowano następnie odpowiednie cyfry: 1 - dla norm stenowych od 1 do 4, oznaczających wyniki niskie, 2 - dla norm stenowych 5-6, oznaczających wyniki przeciętne oraz 3 - dla norm stenowych 7-10 oznaczających wyniki wysokie. Na podstawie tak wyodrębnionego „Indeksu Zdrowia" wydzielono grupy o niskim, przeciętnym i wysokim poziomie świadomości zdrowotnej. W badaniu przyjęto poziom istotności statystycznej $\mathrm{p}<0,05$.

\section{Aktywność fizyczna młodzieży akademickiej w świetle uzyskanych wyników badań}

W trakcie analizy wyników badań pominięto szczegółowy opis rezultatów uzyskanych przez respondentów w poszczególnych narzędziach badawczych. Skoncentrowano się natomiast na różnicach uzyskanych między grupami o różnym poziomie świadomości, w odniesieniu do aktywności fizycznej. 
Punktem wyjścia dla podejmowanej problematyki badań nad aktywnością fizyczną jest refleksja nad postrzeganiem przez młodzież akademicką profilaktyki zdrowotnej, gdyż to właśnie w znaczącym stopniu determinuje styl życia człowieka, na który składają się m.in.: zwyczaje żywieniowe, podejmowana aktywność fizyczna, radzenie sobie ze stresem czy stosowane używek. $Z$ przeprowadzonych badań wynika, że co trzecia osoba o niskiej świadomości zdrowotnej nie podejmuje refleksji nad profilaktyką zdrowotną. Wśród osób o wysokim poziomie świadomości odsetek ten jest znacznie niższy, gdyż wynosi zaledwie 14,2 proc.. Różnice między wyodrębnionymi grupami można zauważyć także w podejściu do aktywności fizycznej, która jest zasadniczym tematem niniejszej pracy. Zaledwie jedna trzecia osób o niskiej świadomości zdrowotnej uprawia sport, natomiast w przypadku osób świadomych ważności uprawiania sportu odsetek ten wzrasta do prawie 53 proc. Wyniki uzyskane $w$ trakcie dalszych analiz, opartych na podstawie testu niezależności dwóch zmiennych $\chi^{2}$, okazały się być nieistotne statystycznie. W związku z otrzymanymi rezultatami postanowiono poddać komponent aktywności fizycznej dalszym badaniom.

Wpływ aktywności fizycznej na zdrowie uwarunkowany jest właściwą częstotliwością uprawiania sportu. W związku z powyższym badani wskazali na to, jak często podejmują aktywność fizyczną. Otrzymane rezultaty przedstawiono w tabeli 1.

Tabela 1. Częstotliwość uprawiania sportu wśród studentów w odniesieniu do różnych poziomów świadomości zdrowotnej i pór roku

\begin{tabular}{|c|c|c|c|c|c|c|c|c|c|}
\hline \multirow{3}{*}{$\begin{array}{l}\text { Poziom } \\
\text { świado- } \\
\text { mości }\end{array}$} & \multicolumn{9}{|c|}{ Jak często uprawiasz sport? } \\
\hline & \multirow[b]{2}{*}{ odpowiedzi } & \multicolumn{2}{|c|}{ wiosna } & \multicolumn{2}{|c|}{ lato } & \multicolumn{2}{|c|}{ jesień } & \multicolumn{2}{|c|}{ zima } \\
\hline & & $\mathbf{n}$ & proc. & $\mathbf{n}$ & proc. & $\mathbf{n}$ & proc. & $\mathbf{n}$ & proc. \\
\hline \multirow{7}{*}{ Niski } & $\begin{array}{l}\text { Nie uprawiam } \\
\text { żadnych } \\
\text { sportów }\end{array}$ & 34 & 17 & 27 & 13,5 & 52 & 26 & 78 & 39 \\
\hline & $\begin{array}{l}\text { Jeden raz } \\
\text { w tygodniu }\end{array}$ & 39 & 19,5 & 25 & 12,5 & 43 & 21,5 & 54 & 27 \\
\hline & $\begin{array}{l}\text { Dwa razy } \\
\text { w tygodniu }\end{array}$ & 47 & 23,5 & 37 & 18,5 & 58 & 29 & 34 & 17 \\
\hline & $\begin{array}{l}\text { Trzy razy } \\
\text { w tygodniu }\end{array}$ & 32 & 16 & 37 & 18,5 & 16 & 8 & 13 & 6,5 \\
\hline & $\begin{array}{l}\text { Kilka razy } \\
\text { w tygodniu }\end{array}$ & 36 & 18 & 54 & 27 & 24 & 12 & 16 & 8 \\
\hline & \begin{tabular}{|l} 
Codziennie \\
\end{tabular} & 12 & 6 & 20 & 10 & 7 & 3,5 & 5 & 2,5 \\
\hline & Ogółem: & 200 & 100 & 200 & 100 & 200 & 100 & 200 & 100 \\
\hline
\end{tabular}




\begin{tabular}{|c|c|c|c|c|c|c|c|c|c|}
\hline \multirow{3}{*}{$\begin{array}{l}\text { Poziom } \\
\text { świado- } \\
\text { mości }\end{array}$} & \multicolumn{9}{|c|}{ Jak często uprawiasz sport? } \\
\hline & \multirow{2}{*}{ odpowiedzi } & \multicolumn{2}{|c|}{ wiosna } & \multicolumn{2}{|c|}{ lato } & \multicolumn{2}{|c|}{ jesień } & \multicolumn{2}{|c|}{ zima } \\
\hline & & $\mathbf{n}$ & proc. & $\mathbf{n}$ & proc. & $\mathbf{n}$ & proc. & $\mathbf{n}$ & proc. \\
\hline \multirow{7}{*}{ Przeciętny } & $\begin{array}{l}\text { Nie } \\
\text { uprawiam } \\
\text { żadnych } \\
\text { sportów }\end{array}$ & 23 & 9,6 & 19 & 7,9 & 46 & 19,2 & 86 & 35,8 \\
\hline & $\begin{array}{l}\text { Jeden raz } \\
\text { w tygodniu }\end{array}$ & 40 & 16,7 & 29 & 12,1 & 67 & 27,9 & 68 & 28,3 \\
\hline & $\begin{array}{l}\text { Dwa razy } \\
\text { w tygodniu }\end{array}$ & 50 & 20,8 & 31 & 12,9 & 50 & 20,8 & 28 & 11,7 \\
\hline & $\begin{array}{l}\text { Trzy razy } \\
\text { w tygodniu }\end{array}$ & 39 & 16,3 & 35 & 14,6 & 28 & 11,7 & 22 & 9,2 \\
\hline & $\begin{array}{l}\text { Kilka razy } \\
\text { w tygodniu }\end{array}$ & 70 & 29,2 & 91 & 37,9 & 38 & 15,8 & 28 & 11,7 \\
\hline & Codziennie & 18 & 7,5 & 35 & 14,6 & 11 & 4,6 & 8 & 3,3 \\
\hline & Ogółem: & 240 & 100 & 240 & 100 & 240 & 100 & 240 & 100 \\
\hline \multirow{7}{*}{ Wysoki } & $\begin{array}{l}\text { Nie upra- } \\
\text { wiam żad- } \\
\text { nych sportów }\end{array}$ & 10 & 6,8 & 8 & 5,4 & 24 & 16,3 & 43 & 29,3 \\
\hline & $\begin{array}{l}\text { Jeden raz } \\
\text { w tygodniu }\end{array}$ & 28 & 19 & 12 & 8,1 & 34 & 23,1 & 37 & 25,2 \\
\hline & $\begin{array}{l}\text { Dwa razy } \\
\text { w tygodniu }\end{array}$ & 31 & 21,1 & 24 & 16,2 & 33 & 22,4 & 24 & 16,3 \\
\hline & $\begin{array}{l}\text { Trzy razy } \\
\text { w tygodniu }\end{array}$ & 21 & 14,3 & 28 & 18,9 & 19 & 12,9 & 16 & 10,9 \\
\hline & $\begin{array}{l}\text { Kilka razy } \\
\text { w tygodniu }\end{array}$ & 46 & 31,3 & 51 & 34,5 & 32 & 21,8 & 23 & 15,6 \\
\hline & Codziennie & 11 & 7,5 & 25 & 16,9 & 5 & 3,4 & 4 & 2,7 \\
\hline & Ogółem: & 147 & 100 & 148 & 100 & 147 & 100 & 147 & 100 \\
\hline
\end{tabular}

Źródło: badania własne.

Uzyskane wartości wskazują na to, że grupy wydzielone na podstawie „Indeksu Świadomości Zdrowotnej” są zróżnicowane pod względem podejmowanej aktywności fizycznej. Niezależnie od pory roku osoby prezentujące niski poziom świadomości zdrowotnej częściej nie uprawiają żadnych sportów niż badani o przeciętnym i wysokim poziomie świadomości. Zdaniem respondentów, wiosna i lato $\mathrm{w}$ większym stopniu sprzyjają podejmowanej przez nich aktywności niż jesień i zima. Osoby zorientowane na zdrowie częściej niż pozostałe dwie grupy studentów uprawiają sport kilka razy w tygodniu. Dalsze analizy oparte na podstawie testu 
niezależności dwóch zmiennych $\chi^{2}$ pokazały istotne statystyczne różnice w zakresie częstotliwości uprawiania sportu przez młodzież akademicką $\chi^{2}(15, \mathrm{n}=589)$ $=28,46 ; \mathrm{p}=0$,019.

Biorąc pod uwagę wpływ aktywności fizycznej na zdrowie jednostki, zastanawiający jest fakt, że pomimo licznych kampanii społecznych, edukacji zdrowotnej, prowadzonej już od najmłodszych lat, oraz wychowania na rzecz zdrowia, nadal spora grupa studentów w ogóle nie uprawia sportu. Potencjalne przyczyny takiego stanu rzeczy zaprezentowano na wykresie 1.

Wykres 1. Różnice w określeniu przyczyn braku aktywności fizycznej (proc.) między grupami o różnym poziomie świadomości zdrowotnej

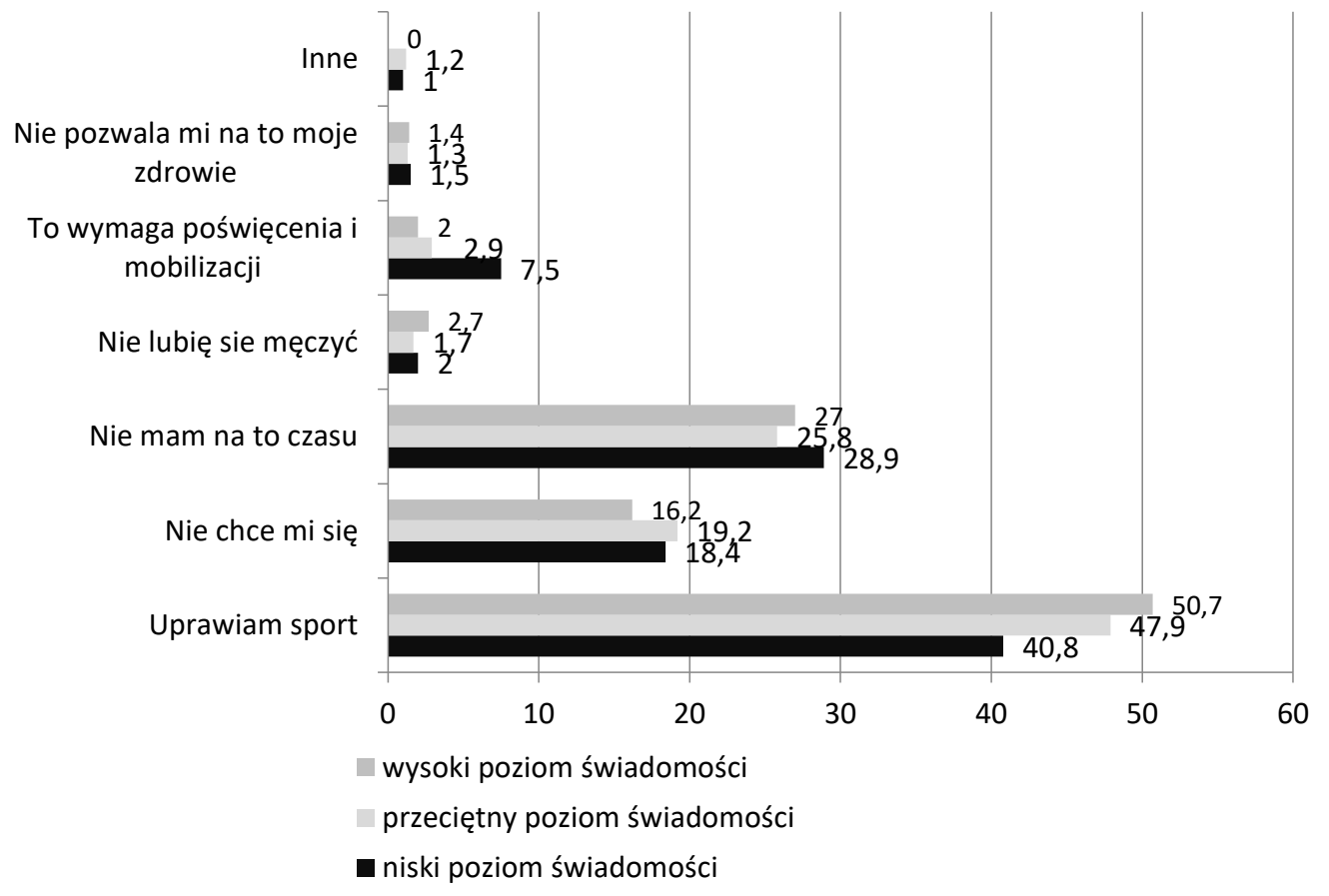

Źródło: badania własne.

Okazuje się, że główną przyczyną braku ruchu jest brak czasu, na co wskazuje prawie jedna trzecia respondentów ze wszystkich wyodrębnionych grup na podstawie „Indeksu Świadomości Zdrowotnej”. Wśród pozostałych czynników można wyróżnić lenistwo, przy czym osoby uzyskujące wysokie wyniki w „Indeksie Świadomości Zdrowotnej” wybierały tę odpowiedź najrzadziej spośród wszystkich grup.

\section{Dom rodzinny i najbliższe otoczenie jako źródło troski o zdrowie}

Na podstawie przeprowadzonych badań można zaobserwować, że zdaniem respondentów z wysoką świadomością zdrowotną członkowie ich rodzin częściej uprawiają sport (56,8 proc.) aniżeli członkowie badanych rodzin uzyskujących 
niskie wyniki (49,3 proc.). Może to wskazywać na rolę transmisji wzorców zachowań, nawyków oraz stylu życia, które - systematycznie utrwalane - mogą zostać uwewnętrznione i następnie powtarzane. Test niezależności dwóch zmiennych pokazał różnice istotne statystycznie $\mathrm{w}$ zakresie regularnego uprawiania sportu przez członków rodzin badanych, prezentujących różne poziomy świadomości zdrowotnej $\chi^{2}(57, \mathrm{n}=589)=83,6 ; \mathrm{p}=0,012$ (patrz tabela 2$)$.

Tabela 2. Aktywność fizyczna członków rodzin respondentów w podziale na poziomy świadomości zdrowotnej młodzieży akademickiej

\begin{tabular}{|l|c|c|c|c|c|c|}
\hline \multirow{2}{*}{$\begin{array}{l}\text { Najbliższa } \\
\text { rodzina }\end{array}$} & \multicolumn{6}{|c|}{ Poziom świadomości } \\
\cline { 2 - 8 } & \multicolumn{2}{|c|}{ Niski } & \multicolumn{2}{c|}{ Przeciętny } & \multicolumn{2}{c|}{ Wysoki } \\
\cline { 2 - 8 } & $\mathbf{n}$ & proc. & n & proc. & n & proc. \\
\hline Mama/opiekun & 19 & 9,5 & 16 & 6,7 & 15 & 10,1 \\
\hline Tata/opiekun & 16 & 8 & 11 & 4,6 & 12 & 8,1 \\
\hline Siostra & 21 & 10,4 & 34 & 14,2 & 17 & 11,5 \\
\hline Brat & 36 & 17,9 & 49 & 20,4 & 28 & 18,9 \\
\hline Nikt & 102 & 50,7 & 125 & 52,1 & 64 & 43,2 \\
\hline Inni & 7 & 3,5 & 5 & 2 & 12 & 8,4 \\
\hline Ogółem: & 201 & 100 & 240 & 100 & 148 & 100 \\
\hline
\end{tabular}

Źródło: badania własne.

W otoczeniu osób z wysoką świadomością zdrowotną znajduje się także więcej osób dbających o zdrowie niż wśród respondentów z niską i przeciętną świadomością zdrowotną (patrz wykres 2).

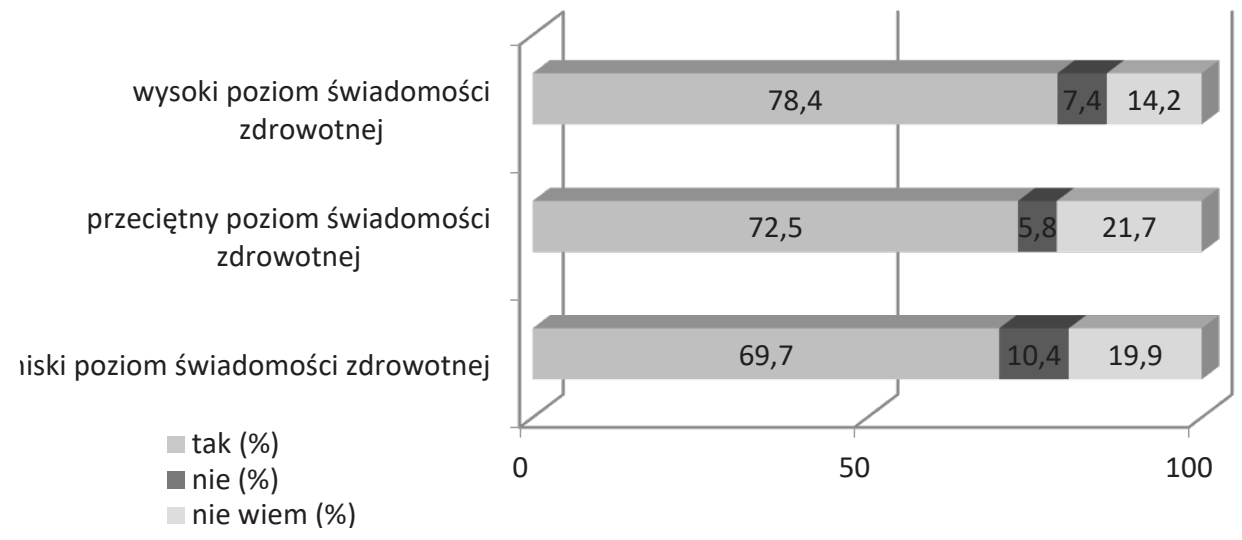

Wykres 2. Czy w Twoim otoczeniu są osoby dbające o zdrowie?

Źródło: badania własne.

Ponad 10 proc. ankietowanych $\mathrm{z}$ niskim poziomem świadomości przyznało, że w ich otoczeniu nie ma osób, które podejmowałyby działania na rzecz zdrowia. 
W przypadku respondentów posiadających wysoki poziom świadomości zdrowotnej odsetek ten wyniósł 7,4 proc., a biorąc pod uwagę osoby o przeciętnej świadomości - 5,8 proc.

Subiektywna ocena respondentów w zakresie określenia wpływu rodziców na ich zdrowotny styl życia pokazuje całkiem zbliżone rezultaty (patrz tabela 3).

Tabela 3. Subiektywna ocena respondentów w zakresie wcielania przez rodziców zdrowego stylu życia w domu rodzinnym

\begin{tabular}{|c|c|c|c|c|c|}
\hline \multirow[t]{2}{*}{$\begin{array}{l}\text { Poziom } \\
\text { świadomości } \\
\text { zdrowotnej }\end{array}$} & \multirow[t]{2}{*}{ Odpowiedzi } & \multicolumn{2}{|c|}{$\begin{array}{l}\text { W jakim stopniu masz } \\
\text { poczucie, że rodzice/ } \\
\text { opiekunowie nauczyli Cię } \\
\text { zdrowego trybu życia? }\end{array}$} & \multicolumn{2}{|c|}{$\begin{array}{c}\text { W jakim stopniu masz } \\
\text { poczucie, że rodzice/ } \\
\text { opiekunowie wcielali } \\
\text { w Twoim rodzinnym } \\
\text { domu zasady zdrowego } \\
\text { stylu życia? }\end{array}$} \\
\hline & & $\mathbf{n}$ & proc. & $\mathbf{n}$ & proc. \\
\hline \multirow{6}{*}{ Niski } & Małym & 12 & 6 & 12 & 6 \\
\hline & $\begin{array}{l}\text { Raczej } \\
\text { małym }\end{array}$ & 23 & 11,4 & 24 & 11,9 \\
\hline & Przeciętnym & 66 & 32,8 & 78 & 38,8 \\
\hline & Dużym & 68 & 33,8 & 61 & 30,3 \\
\hline & $\begin{array}{l}\text { Bardzo } \\
\text { dużym }\end{array}$ & 32 & 15,9 & 26 & 12,9 \\
\hline & Ogółem: & 201 & 100 & 201 & 100 \\
\hline \multirow{7}{*}{ Przeciętny } & Małym & 16 & 6,7 & 19 & 7,9 \\
\hline & \begin{tabular}{|l} 
Raczej \\
małym \\
\end{tabular} & 31 & 12,9 & 39 & 16,3 \\
\hline & Przeciętnym & 77 & 32,1 & 85 & 35,4 \\
\hline & & & & & \\
\hline & Dużym & 81 & 33,8 & 73 & 30,4 \\
\hline & $\begin{array}{l}\text { Bardzo } \\
\text { dużym }\end{array}$ & 35 & 14,6 & 24 & 10 \\
\hline & Ogółem: & 240 & 100 & 240 & 100 \\
\hline
\end{tabular}




\begin{tabular}{|l|l|c|c|c|c|}
\hline \multirow{4}{*}{$\begin{array}{l}\text { Poziom } \\
\text { świadomości } \\
\text { zdrowotnej }\end{array}$} & Odpowiedzi & \multicolumn{2}{|c|}{$\begin{array}{c}\text { W jakim stopniu masz } \\
\text { poczucie, że rodzice/ } \\
\text { opiekunowie nauczyli Cię } \\
\text { zdrowego trybu życia? }\end{array}$} & $\begin{array}{c}\text { W jakim stopniu masz } \\
\text { poczucie, że rodzice/ } \\
\text { opiekunowie wcielali } \\
\text { w Twoim rodzinnym } \\
\text { domu zasady zdrowego } \\
\text { stylu życia? }\end{array}$ \\
\cline { 2 - 6 } & & $\mathbf{n}$ & proc. & $\mathbf{n}$ & proc. \\
\hline \multirow{5}{*}{ Wysoki } & Małym & 8 & 5,4 & 8 & 5,4 \\
\cline { 2 - 6 } & $\begin{array}{l}\text { Raczej } \\
\text { małym }\end{array}$ & 22 & 14,9 & 29 & 19,6 \\
\cline { 2 - 6 } & Przeciętnym & 45 & 30,4 & 41 & 27,7 \\
\cline { 2 - 6 } & Dużym & 49 & 33,1 & 53 & 35,8 \\
\cline { 2 - 6 } & $\begin{array}{l}\text { Bardzo } \\
\text { dużym }\end{array}$ & 24 & 16,2 & 17 & 11,5 \\
\cline { 2 - 6 } & Ogółem: & 148 & 100 & 148 & 100 \\
\hline
\end{tabular}

Źródło: badania własne.

Dalsze analizy wykazały brak różnic istotnych statystycznie.

Osoby o wysokim poziomie świadomości zdrowotnej najczęściej wskazywały samych siebie jako główne źródło motywujące je do działań na rzecz zdrowia (35,1 proc.), podobnie jak i osoby z przeciętnym poziomem świadomości (35 proc.).

Powyższy obraz dopełnia analiza odpowiedzi osób, które mają największy wpływ na respondentów pod kątem ich zdrowia (patrz wykres 3).

Wykres 3. Osoby mające największy wpływ na zdrowie

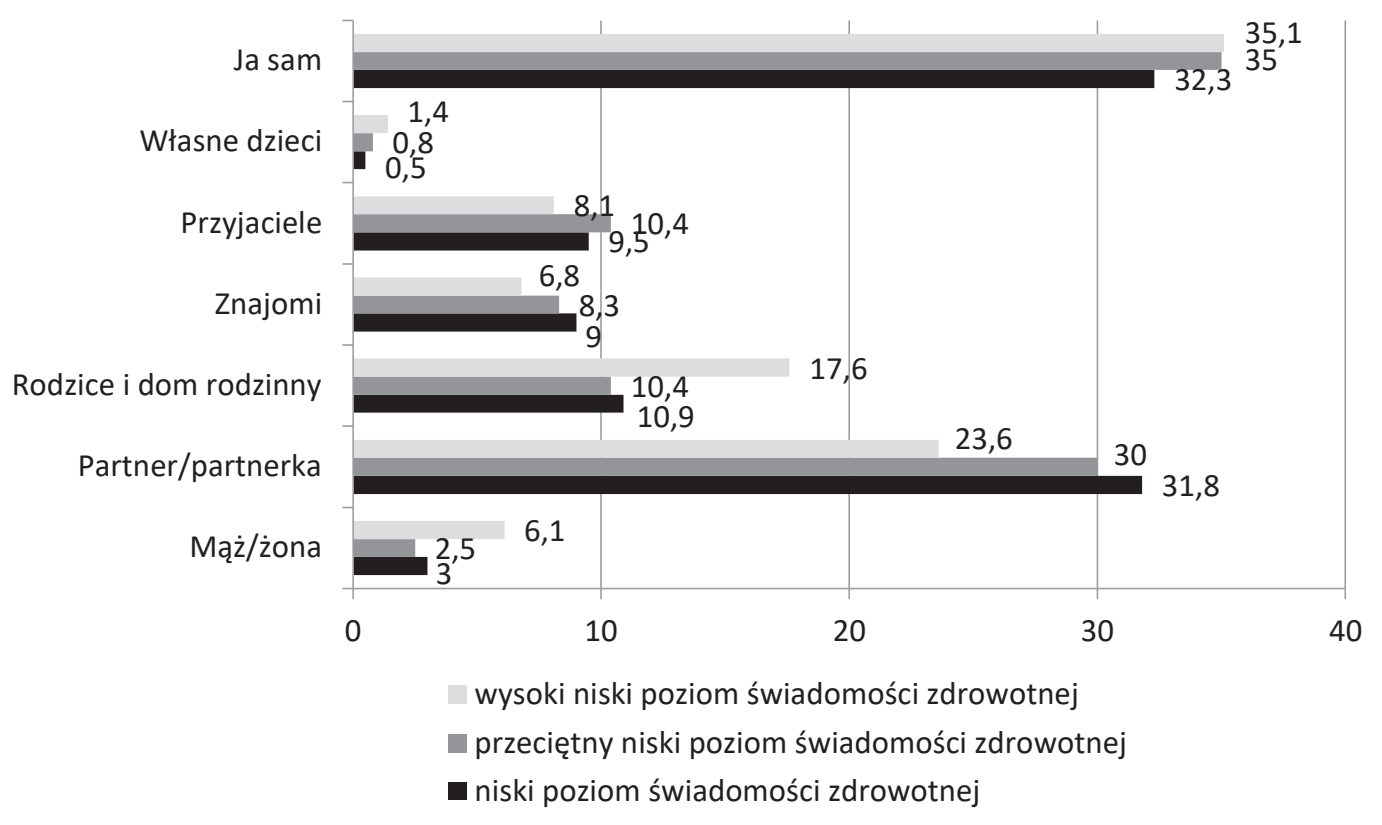

Źródło: badania własne. 
Wpływ na zdrowie wśród osób z niskim poziomem świadomości zdrowotnej mieli partnerzy i partnerki (31,8 proc.). Warto zwrócić uwagę na fakt, że osoby z wysoką świadomością zdrowotną znacznie rzadziej wskazywały na partnerów jako osoby mające jakikolwiek wpływ na ich zdrowie i dużo częściej odpowiadały, że taki wpływ mają rodzice i dom rodzinny - jako miejsce oddziałujące na stan ich zdrowia. Niestety, nadal wyniki uzyskane w tym obszarze są niezwykle słabe. Biorąc pod uwagę fakt, że to rodzice są odpowiedzialni za wychowanie zdrowotne swoich dzieci, rezultaty te wskazują na większą konieczność zaangażowania rodziców w kształtowanie świadomości zdrowotnej ich dzieci oraz uwzględnienia ich roli w strategiach ukierunkowanych na budowanie społeczeństwa zdrowia. Co więcej, należałoby wykorzystać ich potencjał jako źródło kształtowania nawyków i wiedzy w zakresie zdrowia (patrz wykres 4).

Wykres 4. Źródła wiedzy o tematyce zdrowotnej

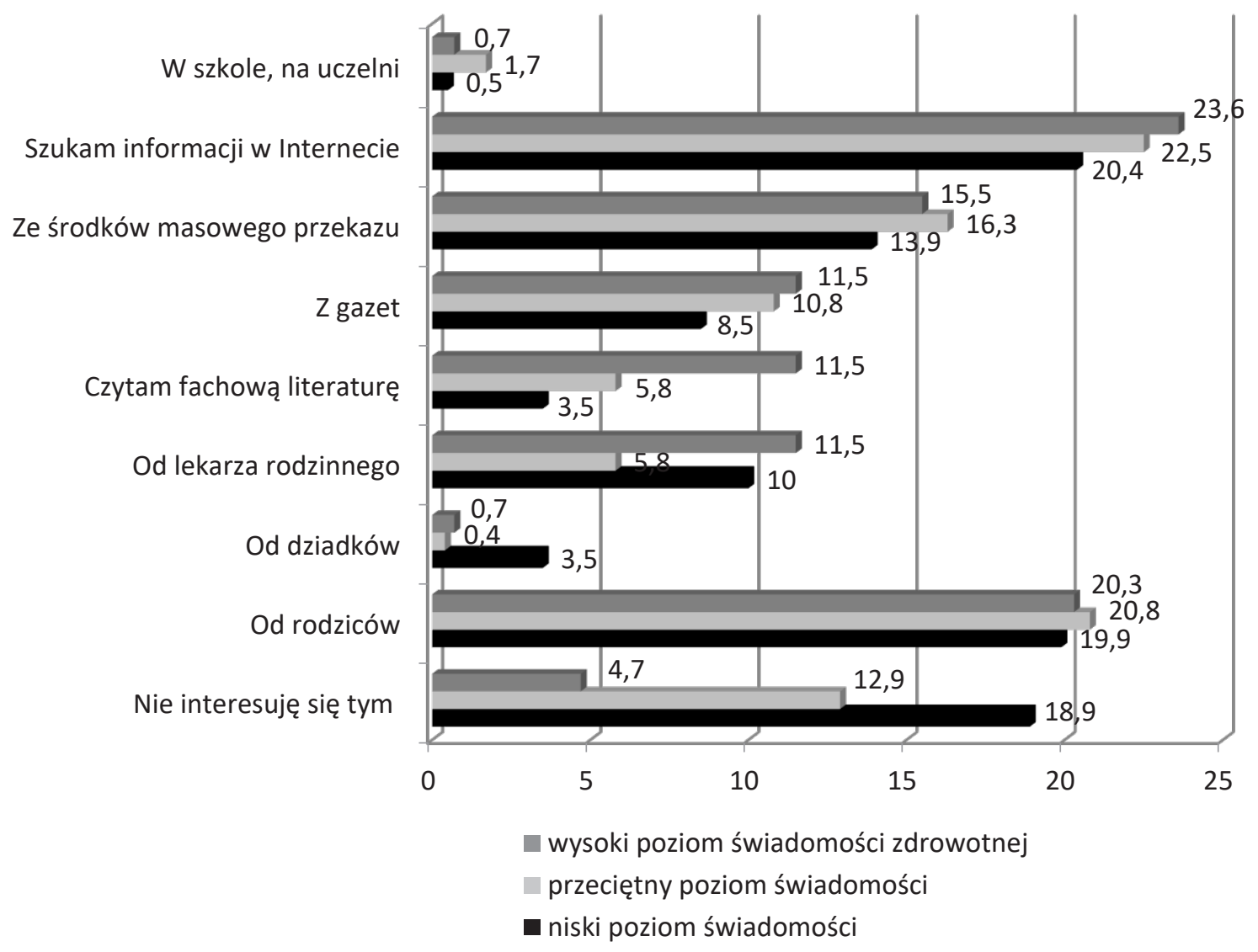

Źródło: badania własne.

Dla większości badanych głównym źródłem zdobywania informacji z zakresu zdrowia jest internet. Podobny odsetek respondentów wskazał na rodzinę. Analizując te wyniki, warto podkreślić fakt, że rola rodziny jest dalece niewykorzystana. Zdobywanie nawyków, jak również pewnych zachowań czy postaw 
zdrowotnych powinno mieć swój początek w rodzinie. Wymaga to więc od rodziców większej świadomości, albowiem to oni poprzez swoje postępowanie dają określony przykład własnym dzieciom. Transfer negatywnych wzorców zachowań i nawyków zdrowotnych przechodzi na późniejsze pokolenia, wzmacniając tym samym zachowania antyzdrowotne. Dodatkowo, prawie co piąty student z niskim poziomem świadomości zdrowotnej nie interesuje się własnym zdrowiem w ogóle, zaś w przypadku osób charakteryzujących się wysokim poziomem świadomości zdrowotnej - odsetek ten wynosi zaledwie 4,7 proc.

\section{Wnioski i podsumowanie}

Zdrowe społeczeństwo jest podstawą rozwoju i prawidłowego funkcjonowania każdego państwa. W związku z tym dużą wagę powinno przykładać się do kształtowania zachowań prozdrowotnych w procesie socjalizacji i wychowania już od najmłodszych lat.

Przeprowadzone badania wskazują na to, że osoby z wysokim poziomem świadomości zdrowotnej $w$ większym stopniu mają prozdrowotne wzorce wyniesione $\mathrm{z}$ domu niż osoby z niskim poziomem świadomości. Oznacza to, że wzorce wyniesione ze środowiska rodzinnego są istotnym elementem wspierającym kształtowanie zdrowego stylu życia. W związku z powyższym, strategia rozwijania świadomości zdrowotnej powinna uwzględniać nie tylko wzmacnianie zachowań prozdrowotnych w środowisku szkolnym czy pozaszkolnym, ale przede wszystkim rodzinnym, co oznacza znaczące wsparcie rodziców w działaniach na rzecz zdrowia.

\section{Bibliografia}

Biernat E. (2011). Aktywność fizyczna mieszkańców Warszawy na przykładzie wybranych grup zawodowych. Warszawa: Oficyna Wydawnicza Szkoły Głównej Handlowej.

Binkowska-Bury M. (2009). Zachowania zdrowotne młodzieży akademickiej. Rzeszów: Wydawnictwo Uniwersytetu Rzeszowskiego.

Dornowski M. (2004). Poziom sprawności fizycznej osób studiujących dziennie i zaocznie wychowanie fizyczne w Akademii Wychowania Fizycznego i Sportu w Gdańsku. W: Umiastowska R. (red.). T. 8: Aktywność ruchowa ludzi w różnym wieku. Szczecin: Wydawnictwo Promocyjne „Albatros”.

Florkiewicz B. (2004). Aktywność ruchowa studentów Instytutu Kultury Fizycznej. W: Umiastowska R. (red.). T. 8: Aktywność ruchowa ludzi w różnym wieku. Szczecin: Wydawnictwo Promocyjne „Albatros”.

Gacek M. (2003). Subiektywna ocena zdrowia młodzieży akademickiej $w$ zależności od niektórych cech osobowości. „Annales Universitatis Mariae Curie-Skłodowska", Sectio D, t. 66, nr 13, s. 365-369. 
Gaweł A. (2003). Pedagodzy wobec wartości zdrowia. Kraków: Wydawnictwo Uniwersytetu Jagiellońskiego.

Grabara M., Szopa J. (2011). Health benefits of doing physical exercises yoga reported by the students of the Academy of Physical Education in Katowice. „Polish Journal of Sports Medicine", t. 27, nr 2, s. 123-132.

Juczyński Z. (2001). Narzędzia pomiaru w promocji zdrowia i psychologii zdrowia. Warszawa: Pracownia Testów Psychologicznych Polskiego Towarzystwa Psychologicznego, s. 116-122.

Kijo P. (2004). Aktywność ruchowa studentów wychowania fizycznego izdrowotnego Uniwersytetu Łódzkiego. W: Umiastowska R. (red.). T. 8: Aktywność ruchowa ludzi w różnym wieku. Szczecin: Wydawnictwo Promocyjne „Albatros”.

Krajewska A., Słowik-Gabryelska A. (2008). Aktywność sportowa studentów i studentek zdrowia publicznego Uniwersytetu Szczecińskiego w kontekście stanu odżywienia i jakości żywienia. W: Umiastowska R. (red.). T. 12: Aktywność ruchowa ludzi w różnym wieku. Szczecin: Wydawnictwo Promocyjne „Albatros”.

Kreuter M. W. (1976). An Interaction Model to Facilitate Health Awareness and Behavior Change. „Journal of School Health”, nr 46, s. 543-545.

Makuła W. (1999). Postawy prosomatyczne młodzieży akademickiej Krakowa. „Kultura Fizyczna”, nr 3/4, s. 7-9.

Molewski M., Wieczorek A., Jadczak Ł., Wieczorek J., Śliwowski R. (2012). Physical activity of selected students groups of different countries. W: Szeklicki R., Maciaszek J., Osiński W. (red.). Aktywność i sprawność fizyczna w edukacji, sporcie i promocji zdrowia. Poznań: Bogucki Wydawnictwo Naukowe.

Nowak-Zaleska A., Zaleski R. (2004). Kształtowanie zdrowego stylu życia młodzieży akademickiej Trójmiasta poprzez jej udział w rekreacji i sporcie. „Annales Universitatis Mariae Curie-Skłodowska", Sectio D, nr 38 (14), s. 231-235.

Pawlik J. (2003). Zachowania zdrowotne studentów pedagogiki. „Wychowanie Fizyczne i Zdrowotne", nr 3, s. 10-12.

Popławska H., Huk-Wieliczuk E. (1997). Zagrożenia zdrowia i aktywności fizycznej wynikające z nieprawidłowego stylu życia studentów Wyższej Szkoły Rolniczej w Siedlcach. W: Umiastowska D. (red.) Aktywność ruchowa ludzi w różnym wieku: III Konferencja Naukowa Szczecin 4-5 grudnia 1997: materiały naukowe $n r$ 3. Szczecin: Wydawnictwo Promocyjne „Albatros”.

Ratajczak Z. (1997). Model zachowania się człowieka wobec własnego zdrowia. Wnioski dla praktyki promocyjnej. W: Ratajczak Z., Heszen-Niejodek I. (red.). Promocja zdrowia. Psychologiczne podstawy wdrożeń. Katowice: Wydawnictwo Uniwersytetu Śląskiego.

Sochocka L., Wojtyłko A. (2013). Aktywność fizyczna studentów studiów stacjonarnych kierunków medycznych i niemedycznych. „Medycyna Środowiskowa - Environmental Medicine", t. 16, nr 2, s. 53-58. 
Suliga E. (red.). (2004). Zachowania zdrowotne studentów kieleckich i uczniów szkół ponadgimnazjalnych w południowej iśrodkowo-wschodniej Polsce. Kielce: Wydawnictwo Akademii Świętokrzyskiej im. Jana Kochanowskiego.

Szczodrowska A., Krysiak W. (2013). Analiza wybranych zwyczajów żywieniowych oraz aktywności fizycznej studentów łódzkich szkół wyższych. „Problemy Higieny i Epidemiologii", t. 94, nr 3, s. 518-521.

Woynarowska B. (2010). Edukacja zdrowotna. Podręcznik akademicki. Warszawa: Wydawnictwo Naukowe PWN.

Zachowania zdrowotne. Zagadnienia teoretyczne, próba charakterystyki zachowań zdrowotnych społeczeństwa polskiego (1990). Gniazdowski A. (red.). Łódź: IMR. Zarzycki P. (2004). Motywy uprawiania pieszej turystyki górskiej w opinii młodzieży studiujacej. W: Umiastowska R. (red.). T. 8: Aktywność ruchowa ludzi w różnym wieku. Szczecin: Wydawnictwo Promocyjne „Albatros”.

\title{
WHEN PEOPLE AROUND YOU MATTER: HEALTH AWARENESS AND SOCIAL PATTERNS AS DETERMINANTS OF THE LEVEL OF PHYSICAL ACTIVITY OF STUDENTS
}

\begin{abstract}
The article tackles the problem of physical activity in opinion of Warsaw universities' students. A new model of health awareness is introduced. On its basis three groups of students with high, average, and low level of health awareness were separated which was a main criterion that differentiated the role of family and the closest circle in pro-health behaviour. The research shows that students with a high level of health awareness are more often surrounded by health oriented people who do sport. Such a result may be connected with a transmission of health behaviour patterns and reciprocal motivation for health.
\end{abstract}

Keywords: health, health awareness, physical activity of students, pro-health surrounding, health oriented behavior.

Adamina Korwin-Szymanowska - doktor pedagogiki, adiunkt w Akademii Pedagogiki Specjalnej w Warszawie. Zainteresowania badawcze: edukacja zdrowotna, edukacja przyrodnicza, outdoor education, edukacja dla zrównoważonego rozwoju. Wybrane publikacje: Edukacja dla zrównoważonego rozwoju w kształceniu nauczycieli (współautorka, 2016, ), Figurative dimensions of health: a corpus-illustrated study (współautorka, 2017,) Adres e-mailowy: adamina_k@wp.pl. 